\title{
Isolasi dan Identifikasi Staphylococcus aureus pada Susu Kambing Peranakan Etawah Penderita Mastitis Subklinis di Kelurahan Kalipuro, Banyuwangi
}

\author{
Isolation and Identification of Staphylococcus aureus in Dairy Milk of The Etawah \\ Crossbred Goat with Subclinical Mastitis in Kalipuro Village, Banyuwangi
}

\author{
Laila Nur Hayati ${ }^{1 *}$, Wiwiek Tyasningsih ${ }^{2}$, Ratih Novita Praja ${ }^{2}$, Sri Chusniati ${ }^{2}$, Maya \\ Nurwartanti Yunita ${ }^{3}$, Prima Ayu Wibawati ${ }^{4}$ \\ ${ }^{1}$ Pendidikan Profesi Dokter Hewan, \\ ${ }^{2}$ Departemen Mikrobiologi Veteriner, \\ ${ }^{3}$ Departemen Patologi Klinik Veteriner, \\ ${ }^{4}$ Departemen Kesehatan Masyarakat Veteriner, \\ Fakultas Kedokteran Hewan, PSDKU Banyuwangi, Universitas Airlangga, \\ Jl. Wijaya Kusuma No.113 Mojopanggung, Giri, Banyuwangi \\ *Corresponding author: laila.nur.hayati-2015@fkh.unair.ac.id
}

\begin{abstract}
Abstrak
Staphylococcus aureus merupakan salah satu bakteri yang sering menyebabkan mastitis subklinis pada Kambing Peranakan Etawah (PE) yang menimbulkan kerugian ekonomi yang cukup besar akibat turunnya produksi susu. Penelitian ini bertujuan untuk mengisolasi dan mengidentifikasi Staphylococcus aureus pada susu kambing PE pederita mastitis subklinis di Kelurahan Kalipuro, Banyuwangi. Sampel yang digunakan berupa susu kambing PE yang diambil pada bulan Desember 2018 di Kelurahan Kalipuro, Banyuwangi. Metode sampling yang digunakan yaitu metode purposive sampling dimana kriteria kandang yang menggunakan bahan baku kayu dan bambu, umur kambing PE 2-3 tahun, kambing yang aktif diperah dan terbukti positif 3 dan 4 mastitis subklinis melalui uji CMT. Sampel yag didapat sebanyak 17 kemudian dianalisis laboratorik di laboratorium mikrobiologi Fakultas Kedokteran Hewan Universitas Airlangga Banyuwangi. Tahap isolasi pada media MSA dan dilanjutkan tahap identifikasi dengan menggunakan pewarnaan Gram, uji katalase, uji manitol, uji koagulase dan uji VP. Diperoleh hasil yaitu terdapat 16 (94.1\%) sampel positif Staphylococcus aureus.
\end{abstract}

Kata kunci: Peranakan Etawah, mastitis subklinis, Staphylococcus aureus, susu

\section{Abstract}

Staphylococcus aureus is one of the bacteria that often causes subclinical mastitis in the Etawah Cross Breed (PE) Goat which causes considerable economic losses due to decreased milk production. This study aimed to isolate and identify Staphylococcus aureus in the milk of PE goats with subclinical mastitis in Kalipuro Village, Banyuwangi. The samples were taken from dairy milk of PE goats on December 2018 in Kalipuro Village, Banyuwangi.Purposive sampling was used for the sampling method which have some criteria such as the cages made of wood and bamboo material, PE goats aged 2-3 years and it were actively milked and evidently positive 3 and 4 subclinical mastitis using Californian Mastitis Test (CMT). As many as 17 samples were taken and then analyzed in laboratory microbiology Faculty of Veterinary Medicine Airlangga University. Phase isolated on MSA media and continued with identification using Gram staining, catalase test, mannitol test, coagulase test and VP test. It showed 16 (94.1\%) positive samples of Staphylococcus aureus.

Key words: Etawah Crossbreed, subclinical mastitis, Staphylococcus aureus, milk

Received: 21 Maret 2019

Revised: 16 April 2019

Accepted: 11 Juli 2019

\section{PENDAHULUAN}

Staphylococcus aureus merupakan salah satu bakteri patogen yang sering terdapat dalam susu yang terkontaminasi (Oktaviantris, 2007). Staphylococcus aureus sering menyebabkan mastitis subklinis maupun mastitis kronis, sehingga kejadian mastitis sering dihubungkan 
dengan infeksi Staphylococcus aureus (Swart et al., 1984). Pengalaman tentang proses pemerahan susu dari peternak yang kurang, berpotensi menyebabkan terjadinya mastitis, seperti yang terjadi pada peternakan kambing Peranakan Etawah (PE) di Kelurahan Kalipuro, Banyuwangi. Peternak mengalami kerugian yaitu produksi air susu turun dan kematian anak kambing karena kekurangan kolostrum.

Penelitian ini dilakukan untuk mengetahui ada tidaknya bakteri Staphylococcus aureus pada susu kambing PE di Kelurahan Kalipuro, Banyuwangi.

\section{METODE PENELITIAN}

Penelitian menggunakan 17 sampel susu kambing PE dari peternakan rakyat di wilayah Kelurahan Kalipuro Banyuwangi yang terbukti positif 3 dan 4 mastitis subklinis. Penentuan mastitis subklinis dilakukan dengan uji Californian Mastitis Test (CMT). Isolasi Staphylococcus aureus dilakukan melalui penanaman pada media Mannitol Salt Agar (MSA), dan Identifikasi dengan pewarnaan Gram, Uji Katalase, Uji gula Mannitol, Uji Koagulase, Uji Voges-Proskauer. Penelitian ini berlangsung di Laboratorium Instrumen Universitas Airlangga PSDKU Banyuwangi.

Sampel susu diambil secara langsung dari kambing PE penderita mastitis subklinis yang terbukti positif 3 dan 4 setelah uji CMT. Sampel ditampung dalam tabung steril kemudian ditutup rapat dan disimpan dalam coolbox yang berisi icepack agar suhunya stabil 5-10 ${ }^{\circ} \mathrm{C}$ untuk menghindari perkembangbiakan bakteri, hingga tiba di laboratorium (Haerah, 2015).

Isolasi bateri pada media MSA dilakukan dengan mengambil 1 ose inokulum dari susu kambing yang terindikasi mastitis, kemudian inokulasikan ke dalam media mannitol, inkubasi selama 24 jam pada suhu $37^{\circ} \mathrm{C}$ (Dewi, 2013). Hasil positif ditunjukkan perubahan warna pada medium dari warna merah menjadi kuning dan hasil negatif tidak ada perubahan warna (Toelle dan Lenda, 2014).

\section{Pewarnaan Gram}

Pewarnaan Gram berfungsi untuk melihat sifat Gram dan morfologi bakteri. Buatlah sediaan ulas diatas object glass lalu difiksasi di atas Bunsen, kemudian ditetesi dengan crystal violet lalu didiamkan selama 1-2 menit. Sisa zat warna dibuang, kemudian dibilas dengan air mengalir. Seluruh preparat ditetesi dengan larutan lugol dan biarkan selama 30 detik. Buang larutan lugol dan bilas dengan air mengalir. Preparat dilunturkan dengan alkohol 96\% sampai semua zat warna luntur, dan segera cuci dengan air mengalir. Teteskan dengan zat warna safranin, biarkan selama 2 menit lalu bilas dengan air mengalir kemudian dibiarkan kering, amati di bawah mikroskop dengan pembesaran lensa objektif 100x memakai emersi (Sarudji, dkk., 2017). Staphylococcus aureus merupakan bakteri Gram positif dan berbentuk kokus bergerombol (Ibrahim, 2017).

\section{Uji Katalase}

Uji katalase berguna untuk membedakan genus Staphylococcus sp.dan Streptococcus sp. Teteskan cairan $\mathrm{H}_{2} \mathrm{O}_{2}$ di atas object glass dan ambil satu ose inokulum dari MSA dan diletakkan kemudian campurkan. Katalase positif ditunjukkan adanya gelembung gas $\left(\mathrm{O}_{2}\right)$ yang diproduksi oleh genus Staphylococcus (Toelle dan Lenda, 2014).

\section{Uji Gula Manitol}

Uji fermentasi manitol dilakukan untuk membedakan Staphylococcus patogen dan nonpatogen dengan menginokulasikan biakan bakteri ke dalam media, selanjutnya diinkubasikan pada suhu $37^{\circ} \mathrm{C}$ selama 24 jam. Uji manitol bersifat positif apabila terlihat perubahan warna menjadi kekuningan dan negatif apabila warnanya tetap merah (Ibrahim, 2017).

\section{Uji Koagulase}

Uji koagulase merupakan uji yang digunakan untuk mengetahui ada tidaknya enzim koagulase yang dihasilkan oleh Staphylococcus $s p$. Uji ini dilakukan dengan mengambil isolat bakteri menggunakan ose, kemudian masukkan 
ke dalam $1 \mathrm{ml}$ Nutrient Broth dan inkubasi pada suhu $37^{\circ} \mathrm{C}$ selama 24 jam. Masukkan $1 \mathrm{ml}$ plasma kelinci ke dalam Nutrient Broth yang sudah berisi bakteri menggunakan spuit. Dan inkubasi selama 4 jam pertama untuk melihat hasilnya, bila masih belum menunjukkan koagulase positif inkubasi dilanjutkan sampai 24 jam. Reaksi positif pada uji koagulase ditunjukkan dengan adanya gumpalan seperti gel dalam tabung, dan reaksi negatif apabila tidak terdapat gumpalan menyerupai gel pada tabung (SNI, 2015).

\section{Uji Voges-Proskauer}

Uji Voges Proskauer (VP) berguna mengetahui reaksi kondensasi diantara diacethyl.. Uji VP dikerjakan dengan memupuk koloni Staphylococcus pada media VP dalam tabung dan diinkubasi selama 40 jam pada suhu $37^{\circ} \mathrm{C}$. Pertumbuhan bakteri ditandai dengan warna media yang menjadi keruh, kemudian ditambahkan ke dalam tabung 5 tetes $\mathrm{KOH} 40 \%$ dalam akuades steril dan 12 tetes alpha-napthol $5 \%$ dalam ethanol, yang bertindak sebagai katalis. Larutan yang telah ditambah reagen kemudian dikocok perlahan dan tunggu sampai 30 menit. Hasil positif terjadi perubahan warna dari kuning menjadi merah dan hasil negatif ditandai dengan tidak adanya perubahan warna merah pada tabung (Sarudji dkk., 2017).

\section{HASIL DAN PEMBAHASAN}

Berdasarkan hasil uji CMT pada sampel susu yang diambil dari peternakan kambing PE di daerah kelurahan kalipuro, kecamatan kalipuro, Banyuwangi, didapat 17 sampel yang positif 3 dan 4 mastitis subklinis. Kejadian mastitis berhubungan dengan faktor risiko seperti manajemen pemerahan yang kurang higienis, pemerahan yang tidak tuntas serta sanitasi kandang yang kurang baik. Kurangnya perhatian peternak terhadap aspek-aspek pemerahan tersebut membuat tingginya angka mastitis di daerah Kalipuro. Tidak dilakukannya dipping pada puting setelah dilakukan pemerahan diduga juga sebagai penyebab tingginya angka mastitis.
Sesuai dengan hasil penelitian yang dilakukan Priono dkk. (2016) yang menunjukkan bahwa dipping menggunakan antiseptik pada ambing kambing PE berpengaruh nyata terhadap jumlah koloni bakteri Staphylococcus aureus. Disebabkan dipping puting dapat mencegah mikroorganisme masuk kedalam ambing ketika puting masih terbuka setelah ambing diperah. Larutan dipping bekerja dengan cara melapisi dinding jaringan ambing dengan zat aktif dalam antiseptik sehingga mencegah mikroorganisme masuk dan berkembang.

Sampel susu dari uji CMT ini kemudian akan diisolasi pada media MSA. Hasil isolasi pada media MSA, dari 17 sampel didapatkan 16 sampel yang diduga bakteri Staphylococcus aureus (Gambar 1). Staphylococcus aureus memiliki kemampuan untuk memfermentasikan manitol. Dapat dibuktikan bila Staphylococcus aureus dibiakkan dalam agar Manitol, dimana terjadi perubahan perubahan warna dari merah ke kuning (Arif, 2017). Satu sampel sisanya tidak ditumbuhi bakteri kemungkinan karena dalam sampel susu tersebut tidak ada bakteri Staphylococcus sp., karena menurut Sarudji dkk. (2017), MSA merupakan media selektif dan diferensial untuk identifikasi Staphylococcus sp.. Media ini mengandung garam natrium klorida $7.5 \%$ sehingga media ini menjadi media selektif. Karena sebagian besar bakteri tidak dapat tumbuh pada konsenterasi garam $7.5 \%$ kecuali Staphylococcus.

Hasil isolasi bakteri yang positif memfermantasi mannitol kemudian dilakukan pewarnaan Gram. Staphylococcus aureus merupakan bakteri Gram positif dan berbentuk kokkus yang menghasilkan warna ungu pada pewarnaan Gram (Gambar 1). Warna ungu disebabkan karena bakteri mempertahankan warna pertama, yaitu Kristal violet. Perbedaan sifat Gram dipengaruhi oleh kandungan pada dinding sel, yaitu bakteri Gram positif kandungan peptidoglikan lebih tebal jika dibanding dengan Gram negatif (Dewi, 2013).

Menurut Arif (2017) Staphylococcus menghasilkan enzim katalase yang mampu menghidrolisis hidrogen peroksida $\left(\mathrm{H}_{2} \mathrm{O}_{2}\right)$ menjadi air $\left(\mathrm{H}_{2} \mathrm{O}\right)$ dan gelembung gas $\left(\mathrm{O}_{2}\right)$. 

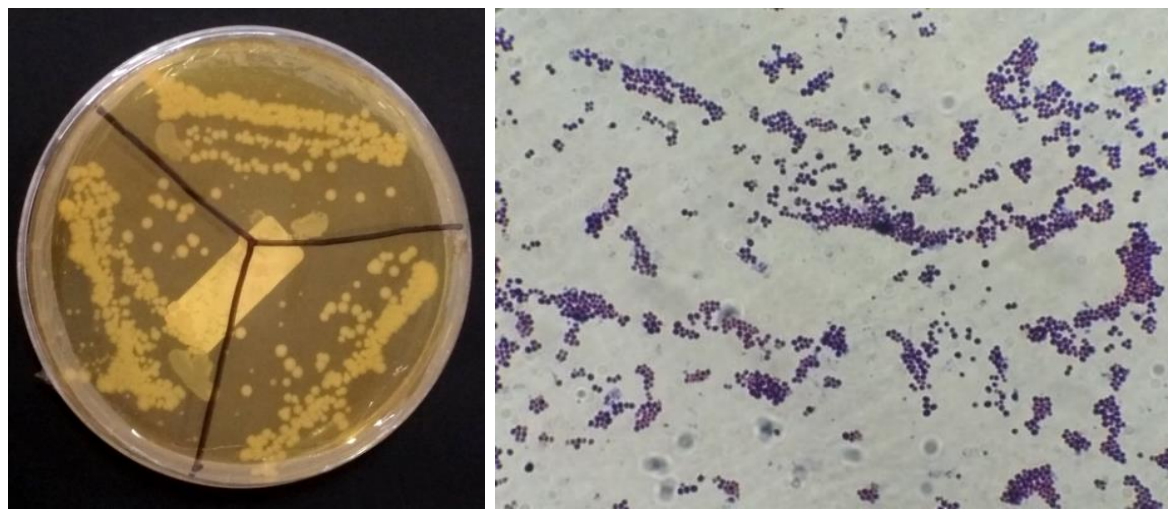

Gambar 1. Isolat Staphylococcus aureus pada media MSA dan pewarnaan gram mikroskopis

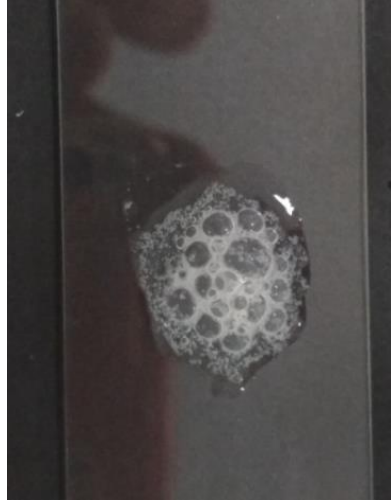

Gambar 2. Uji katalase positif

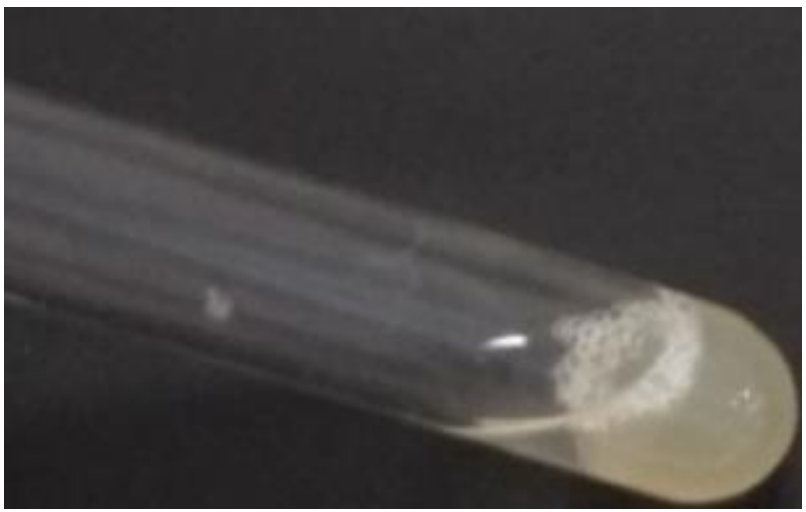

Gambar 4. Uji koagulase positif

Berdasarkan hasil uji katalase (Gambar 2), 19 isolat bakteri terlihat semua positif bergelembung yang membuktikan bahwa isolate tersebut merupakan Staphylococcus (Purnomo et al., 2006).

Isolat yang sudah dilakukan uji katalase kemudian dilanjutkan dengan uji konfirmasi manitol. Staphylococcus sp. yang bersifat patogen mampu memfermentasi gula yang terdapat didalam larutan mannitol sehingga meningkatkan kadar asam dan mengubah warna larutan menjadi kuning (Singh dan Prakash

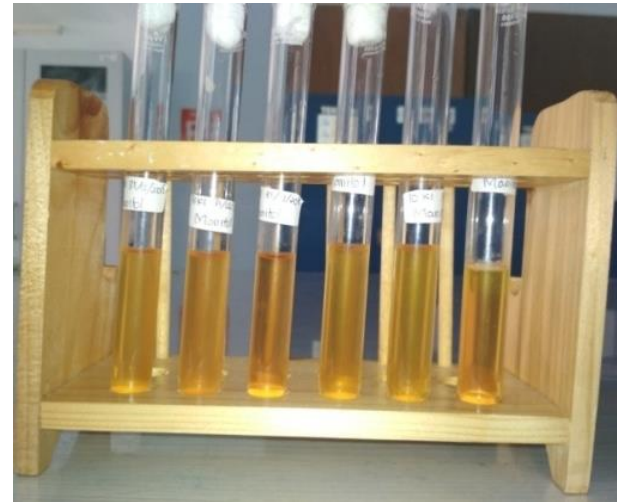

Gambar 3. Uji manitol positif

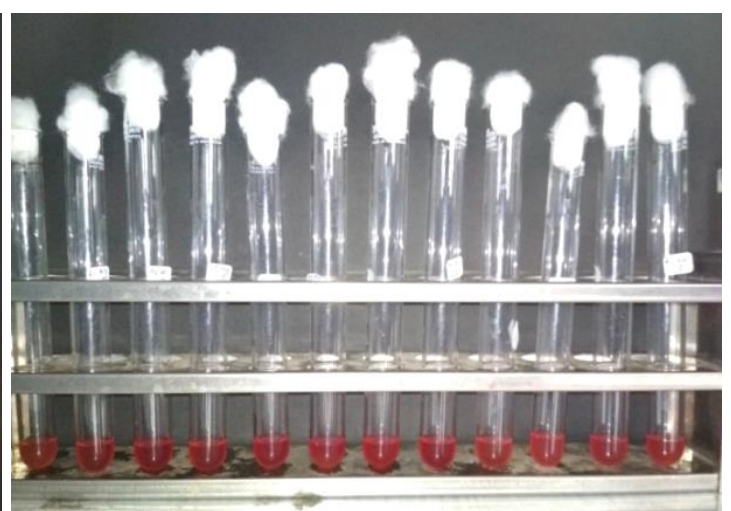

Gambar 5. Uji VP positif

2008). Uji fermentasi mannitol secara anaerob dilakukan dikarenakan Staphylococcus aureus memiliki sifat anaerob fakultatif yang dapat memfermentasi glukosa dalam keadaan tidak ada oksigen (Gambar 3). Staphylococcus aureus merupakan bakteri patogen sehingga sampel positif ditandai dengan adanya perubahan warna kuning pada media (Maulitasari, 2014).

Uji koagulase dilakukan untuk mengetahui adanya enzim koagulase (Gambar 4), dimana enzim ini merupakan protein ekstraseluler yang dihasilkan oleh Staphylococcus aureus yang 
dapat menggumpalkan plasma (Dewi, 2014). Penggumpalan plasma terjadi dikarenakan terdapat protein yang menyerupai enzim yang bila ditambahkan oksalat atau sitrat dapat menyebabkan penggumpalan. Faktor serum bereaksi dengan koagulase untuk membentuk esterase, aktivitas penggumpalan, dan mengaktivasi protrombin menjadi trombin. Trombin akan membentuk fibrin yang berpengaruh terhadap terjadinya penggumpalan plasma (Boerlin, 2003). Kemampuan menggumpalkan plasma merupakan salah satu faktor virulensi yang penting dalam patogenesis S. aureus (Ote et al., 2011).

Uji VP digunakan untuk mengidentifikasi organisme yang mampu menghasilkan acetoin dari pendegradasian glukosa selama fermentasi 2,3 butanadiol (Gambar 5). Hasil metabolisme ini mengalami oksidasi dengan hasil akhirnya adalah $\mathrm{KOH}, \mathrm{O} 2$ dan beberapa bahan lain (creatinin). Pembentukan warna merah atau pink akan terjadi setelah penambahan Barritt's Reagen dengan pembentukan asetil metil karbinol yang menandakan uji bersifat positif. Uji bersifat negatif ditandai dengan tidak terjadinya perubahan warna (Sarudji dkk., 2017). Acetyl-methyl-carbinol adalah salah satu hasil produk pemecahan dextrose oleh enzim bakteri (Dewi, 2013).

Berdasarkan hasil isolasi dan identifikasi dari 17 sampel susu kambing PE yang positif mastitis subklini 3 dan 4, didapatkan 16 (94\%) sampel yang positif Staphylococcus aureus. Sesuai dengan penelitian sebelumnya yang dilakukan di Polewali Mandar, didapatkan 6 (100\%) sampel susu Kambing PE positif mastitis mengandung bakteri Staphylococcus aureus (Arif, 2017). Penelitian lain yang dilakukan oleh Mustapa (2017) menyatakan bahwa 10 (100\%) sampel susu Kambing PE yang mengalami mastitis teridentifikasi penyebabnya adalah Staphylococcus aureus.

Sumber Staphylococcus aureus berasal dari kulit di sekitar ambing, tangan pemerah, kain yang digunakan untuk mengeringkan ambing, mesin pemerah dan lingkungan sekitar kandang. Infeksi terjadi saat kondisi otot dari puting susu terbuka dan Staphylococcus aureus masuk melalui teat canal. Sebanyak $10^{2}$ Colony Forming Unit (CFU) Staphylococcus aureus mampu menimbulkan mastitis (Moroni et al., 2005). Tahap selanjutnya terjadi respon imun pada kambing. Respon pertahanan yang pertama ditandai dengan berkumpulnya leukosit-leukosit untuk mengeliminasi mikroorganisme yang telah menempel pada sel-sel ambing. Apabila respon ini gagal, maka mikroorganisme akan mengalami multiplikasi dan kambing dapat memperlihatkan respon yang lain, misalnya demam. Bila hewan lemah maka akan terjadi mastitis (Pradika et al., 2019).

Kejadian mastitis pada kambing PE sangat mengancam kelangsungan hidup anaknya, karena selain menurunnya kamampuan produksi susu, toksin yang dihasilkan oleh Staphylococcus aureus juga dapat menyebabkan kematian induknya. Mastitis pada kambing PE akibat Staphylococcus aureus selain sebagai faktor penyebab kematian anak dan induknya juga dapat meyebabkan kerugian ekonomi yang cukup besar akibat turunnya produksi susu. Infeksi intramammary gland pada kambing akibat Staphylococcus aureus ini pada umumnya bersifat subklinis. Staphylococcus aureus dalam susu segar dan produk pangan dapat menyebabkan toxic schock syndrome akibat keracunan pangan. Staphylococcal enterotoxin merupakan agen yang menyebabkan sindrom keracunan dalam makanan pada manusia maupun hewan (Purnomo et al., 2006).

Manajemen pemerahan merupakan salah satu tindakan preventif yang perlu dilakukan untuk mengontrol mastitis. Pencelupan puting sebelum dan sesudah pemerahan, pemberian antibiotika saat kering laktasi merupakan alternatif untuk pencegahan terhadap mastitis klinis maupun subklinis. Pemeriksaan secara rutin terhadap susu menggunakan CMT perlu dilakukan untuk monitoring mastitis subklinis. Penggunaan air bersih untuk mencuci ambing sebelum diperah juga berperanan dalam mencegah mastitis (Purnomo et al., 2006). 


\section{KESIMPULAN}

Sebanyak $16(94.1 \%)$ isolat susu positif Staphylococcus aureus dari susu kambing Peranakan Etawah penderita mastitis subklinis di Kelurahan Kalipuro Banyuwangi.

\section{UCAPAN TERIMA KASIH}

Peneliti mengucapkan terimakasih kepada petugas Dinas Pertanian Banyuwangi telah mendampingi penelitian di Kelurahan Kalipuro.

\section{DAFTAR PUSTAKA}

Arif, A. 2017. Uji Sensitivitas Ampisilin, Imipenem Dan Tetrasiklin Terhadap Staphylococcus Penyebab Mastitis Pada Kambing Peranakan Etawa Asal Kabupaten Asal Kabupaten Polewali Mandar. Program Studi Kedokteran Hewan, Fakultas Kedokteran, Universitas Hasanuddin, Makssar.

Badan Standarisasi Nasional. 2015. SNI 2332.9:2011. Cara Uji Mikrobiologi-bagian 9: Penentuan Staphylococcus aureus Pada Produk Perikanan. Dewan Standardisasi Nasional, Jakarta.

Boerlin, P., Kuhnert, P., Hussy, D., Schaellibaum, M. 2003. Methods for Identification of Staphylococcus aureus Isolates In Cases of Bovine Mastitis. J. Clin. Microbiol., 41(2), 767-771.

Dewi, A.K. 2013. Isolasi, Identifikasi dan Uji Sensitivitas Staphylococcus aureus terhadap Amoxicillin dari Sampel Susu Kambing Peranakan Ettawa (PE) Penderita Mastitis di Wilayah Girimulyo, Kulonprogo, Yogyakarta. J. Sain Vet., 31(2), 140-141.

Haerah, D. 2015. Deteksi Staphylococcus aureus Penyebab Mastitis Subklinis Pada Perah Di Kecamatan Cendana Kabupaten Enrekang. Universitas Hasanuddin. Makassar.
Ibrahim, J. 2017. Tingkat Cemaran Bakteri Staphylococcus aureus Pada Daging Ayam Yang Dijual Di Pasar Tradisional Makassar. Jurusan Ilmu Peternakan Fakultas Sains Dan Teknologi Universitas Islam Negeri Alauddin Makassar.

Maulitasari, S.S. 2014. Identifikasi Cemaran Stahpylococcus aureus Pada Daging Ayam Yang Di Jual Di Pasar Tradisonal Dan Modern Di Sekitar Kampus Institut Pertanian Bogor. Fakultas Kedokteran Hewan Institut Pertanian Bogor, Bogor.

Moroni, P., Pison, G., Ruffo, Boetter, P.J. 2005. Risk factors for intramammary infections and relationship with somatic cell counts in Italian dairy goats. Prev. Vet. Med., 69, 163173.

Mustapa, I.S. 2017. Identifikasi Staphylococcus aureus Penyebab Mastitis Pada Kambing Peranakan Etawa Di Kabupaten Polman. Program Studi Kedokteran Hewan Fakultas Kedokteran Universitas Hasanuddin Makassar.

Octaviantris, F.A. 2007. Deteksi Bakteri Staphylococcus aureus Pada Susu Bubuk Skim (Skim Milk Powder). Bogor: Impor. Departemen Ilmu Penyakit Hewan Dan Kesehatan Masyarakat Veteriner, Fakultas Kedokteran Hewan, Institut Pertanian Bogor.

Ote, I., Taminiau, B., Duprez, I.N., Dizier, I., Maiil, J.G. 2011. Genotypic characterization by Polymerase Chain Reaction of Staphylococcus aureus isolates associated with bovine mastitis. Vet. Microbiol., 153, 285-292.

Pradika, A.Y., Chusniati, S., Purnama, M.T.E., Effendi, M.H., Yudhana, A., Wibawati, P.A. 2019. Uji Total Escherichia coli pada Susu Sapi Segar di Koperasi Peternak Sapi Perah (KPSP) Karyo Ngremboko Kecamatan 
Purwoharjo Kabupaten Banyuwangi. J. Med. Vet., 2(1), 1-6.

Priono, D., Kusumanti, E., Harjanti, D.W. 2016. Jumlah bakteri Staphylococcus aureus dan skor California Mastitis Test (CMT) pada susu kambing Peranakan Etawa akibat dipping ekstrak daun Babadotan (Ageratum conyzoides L.). Fakultas Peternakan dan Pertanian Universitas Diponegoro. Jurnal Ilmu-Ilmu Peternakan, 26(1), 52-57.

Purnomo, A., Hartatik, Khusnan, Siti, O.S., Soegiyono. 2006. Isolasi dan Karakterisasi Staphylococcus aureus Asal Susu Kambing Peranakan Ettawa. J. Media Ked. Hewan, 22(3).

Sarudji, S., Chusniati, S., Tyasningsih, W., Handijatno, D. 2017. Petunjuk Praktikum Penyakit Infeksius Progam S-1 Kedokteran
Hewan. Departemen Pendidikan Nasional Fakultas Kedokteran Hewan Universitas Airlangga.

Singh, P., Prakash, A. 2008. Isolation of Escherichia coli, Staphylococcus aureus and Listeria monocytogenes from milk products sold under market conditions at Agra Region. Acta Agric. Slovenica., 1, 83-84.

Swartz, R., Jooste, P.J., Novello, J.C. 1984. Prevalence and types of bacteria associated subclinical mastitis in Bloem Fonte in dairy herds.Vet. Assoc., 51, 61.

Toelle, N.N., Lenda, V. 2014. Identifikasi dan Karakteristik Staphylococcus Sp. dan Streptococcus Sp. dari Infeksi Ovarium Pada Ayam Petelur Komersial. J. Ilmu Ternak, 1(7), 32-37. 